\title{
Contrastive Analysis of the Segmental Phonemes of English and Hausa Languages
}

\author{
Zubairu Malah and Sabariah Md. Rashid
}

\begin{abstract}
The objectives of this study are: (1) to identify the similarities and differences between the segmental phonemes of English and Hausa languages, and (2) to predict learning difficulties among the Hausa ESL learners based on this comparison. Learners of English as a second language (L2) are usually faced with difficulties largely contributed by the features of their first languages (L1). The Hausa speakers in Nigeria learn English as a second language and features of the Hausa language are heavily evident in their spoken English. Among the causes of difficulty in pronouncing English among the Hausa speakers is the segmental deviation. This study compares and contrasts the segmental phonemes of English and Hausa. Behaviorists and Structural linguists in the 1950's and 1960's founded the theoretical foundations of the Contrastive Analysis (CA) and since then, this approach has been employed in the second language acquisition studies. In the course of this study, the researchers employed desk research where data were drawn from archive and then analyzed side-by-side revealing their similarities and differences. The results of the study demonstrate that although Hausa and English have some similar phonemes, the sounds do not behave the same way in the two languages, and Hausa has 47 phonemes when English has 44. Differences in the phonological features between the two languages result in challenges faced by the Hausas in learning English.
\end{abstract}

Index Terms - Contrastive analysis, English, ESL learning, Hausa, segmental deviation, segmental phoneme, L1 interference.

\section{INTRODUCTION}

Segmental and Supra-segmental variations are certainly inevitable in ESL and EFL learning. It is obvious that both segmental and supra-segmental properties of languages have much to do with the intended meanings of speakers. However, we are more concerned with the segmental rather than the supra-segmental variations here. Why do ESL and EFL learners face different challenges in their attempt to achieve Standard English speech? Although linguists have been at logger heads on different issues relating to language studies, they have unanimously agreed that the L1 significantly influences the acquisition of the L2 phonology [1]. Therefore, at the segmental level, some pronunciation difficulties being faced by ESL learners are quite attributable to the phenomenon of negative transfer, where sounds of L1 are erroneously transferred into the target language [2].

The threat of segmental transfer errors are so detrimental

Manuscript received January 24, 2015; revised June 16, 2015.

Zubairu Malah and Sabariah Md. Rashid are with University Putra Malaysia, Malaysia (e-mail: smrashid@upm.edu.my). to the success of ESL learning that they make expressions odd or even unintelligible especially when the listener does not share an L1 with the speaker. To avoid this, ESL learners must master the L2 sounds. Mastering the L2 sounds means having firm understanding of both the phonetic and phonological features of the sounds. The worst pitfalls are the distributions and realizations of the different phonemes [3]. Sometimes, some phonemes in the ESL learner's L1 may be just allophones in English. For example, while /1/ and / / are full phonemes in Russian, the two are both allophones of /1/ in English where using one instead of the other results in oddness. Some allophones of the ESL learner's L1 may also be phonemes in English. For instance, while $/ \mathrm{n} /$ and $/ \mathrm{y} /$, and $/ \mathrm{d} /$ and $/ ð /$ are allophones in Japanese and Spanish respectively, all the four are full phonemes in English. Therefore, Japanese and Spanish learners of English are very likely to distribute the sounds wrongly, and this could lead to unintelligibility [4].

Because this segmental deviation, especially among interlocutors that do not share an L1, jeopardizes the chances of success in oral communication, linguists feel obliged to ameliorate the situation. Segmental deviations have been categorized into three: sound substitution or conflation, consonant deletion and sound addition. This happens, for example, when the L2 learner tries to simplify the pronunciation of the L2 syllable that does not agree with the syllable structure of the L1, or simply to facilitate the pronunciation of difficult L2 sounds [3]. Robert Lado, a renowned linguist, founded an approach to this problem. He proposed that the two languages should be compared so that knowledge of the similarities and differences between the two would go a long way in providing solutions to the learning problems [4].

Taking into consideration the two languages in question, Hausa and English are two disparate languages. Hausa belongs to the Chadic family of languages of the Afroasiatic phylum and is spoken by more than 35 million people in West Africa as a mother tongue, L2 and lingua franca [5]. In northern Nigeria, more than 30 million people speak the language as a mother tongue [6] and English as a second language. Thus, the Hausa speakers also learn ESL. Common to non-native speakers of English such as the Hausas, it is inevitable for the speakers' L1 to interfere with their English accent. With this in mind, this study investigates the English pronunciation learning difficulties among the Hausa ESL learners. This is done by comparing and contrasting the segmental phonemes of the English and Hausa languages, as well as also predicting possible areas of learning difficulties.

\section{A. Problem Statement}

Do all human languages have exactly the same sound 
system, or do all shared sound phonemes behave exactly the same in all languages? What is the possibility of phonemic negative transfer between languages, and how can this make expressions weird? Studies have revealed that languages may share some phonemes but there are mostly differences than similarities [7]. While English has 24 consonants, Cantonese has only 19, and it does not have any voiced plosives or fricatives. The Cantonese speaker would give /men/ for /mæn/ because the /æ/ is missing in the Cantonese inventory [8]. The Indonesians would pronounce [p $\mathrm{p}^{\mathrm{h}} \mathrm{a}: \mathrm{st}$ ] without the aspiration as in the Indonesian word [pagi] because the Indonesian /p/ is not aspirated in all positions [9]. Problems of this nature are equally found in the speech of the Hausa learners of English, and this renders some of their expressions completely awkward/unintelligible.

However, investigations on the sounds of the Hausa language have for long been carried out, but the focus of earlier studies has been to identify and describe the sounds of the language and not to compare or contrast the sounds with those of English. Therefore, a research of this nature is highly imperative in order to highlight areas of phonological divergence between the two languages. This would help the Hausa learners of English and researchers become aware of the 'trouble areas' when it comes to learning to pronounce English words correctly by the Hausas. Nonetheless, results of this study would facilitate researches and predict the areas of English pronunciation difficulties for the Hausa speakers that are largely caused by the differences between the English and Hausa segmental phonemes and the 'transfer' of the phonological features of their native language. Teachers of English to Hausa speakers would also find the findings of this research very helpful.

\section{B. Objectives of the Study}

1) To identify the similarities and differences between the segmental phonemes of English and Hausa languages to determine why the Hausa learners of English have difficulty with some English sounds

2) To predict accurately English pronunciation learning difficulties likely to be faced by the Hausa ESL learners based on the comparison of the two sound systems

\section{Significance of the Study}

It is understood that the intrusion by the features of the L1 bedevils the success of the L2 learners and users of the ESL. This intrusion continues to render the English produced by the L2 users as either weird or even unintelligible. This occurs in both spoken and written usages. The L1 elements of a bilingual ESL learner or user manifest in the grammar, phonology or lexis of the forms produced by the bilingual. This study is concerned with the phonological interference. By phonological interference is meant the instances of transfer (negative transfer) that inhibit effective acquisition and performance [1], [2] and [10]. Different studies have focused on aspects of phonologies of English and other languages in attempts to remedy the difficulties faced by the EFL and ESL learners and users. For example, [9] discovered that the Indonesians always pronounce ' $\mathrm{s}$ ' as /s/ even when it comes after a voiced sound as in 'needs' [needz]. This is because the
Indonesian 's' is not realized as /z/.[11] discovered that like the English language, the Tiv language also has plosives like $/ \mathrm{p} /, / \mathrm{b} /$, and $/ \mathrm{t} /$, but the Tiv plosives are not realized as aspirated or devoiced. The Japanese, according to [12], pronounce 'very' as [beri] because the language does not have the /v/ sound in its inventory. All these happen because the segmental phonemes of these languages are either not similar or simply behave differently in different environments.

Therefore, it is essential that studies should heed the pronunciation difficulties among the Hausa ESL learners. The Hausa ESL learners and users should be helped to attain good command in English pronunciation. This study is highly significant because its focus is to unravel the causes of pronunciation difficulties at the segmental level faced by the Hausa ESL learners and users.

\section{Theoretical Framework of the Study}

This study draws its theoretical foundations from the Contrastive Analysis theory founded by the Structural Linguists and Behaviourists of the 1950's and 1960's. Proponents of this theory include Lado [4] and Fries [13]. These scholars were concerned with why some elements of the L2 are more difficult to acquire than others. This approach describes the systems or codes of languages by comparing them with others and predicting areas of difficulties so that the L2 learning difficulties are eased. Lado asserts that the L1 grammatical structure is transferred into the L2 and this causes problems to the L2 learner. He adds that although the similar structures would facilitate learning (positive transfer), the dissimilar structures would certainly inhibit learning (negative transfer/interference). To Lado therefore, the best approach to handle the perils of negative transfer (retroactive transfer) is to compare the systems/codes of the L1 and L2. This is the best way to ease the L2 learning difficulties.

On the other hand, it is well to understand that the CA is significant to L2 learning in three major areas: linguistic studies, language teaching and language assessment. It is on this background that Friest claims that language teaching materials that are prepared based on the careful comparison of the scientific descriptions of L1 and L2 are the most effective. Therefore, the proponents of CA believe that when the systems of both L1 and L2 are comparatively described, areas that would facilitate learning or pose difficulties to the L2 learner would be diagnosed. This would go a long way in helping the learners and teachers overcome the challenges in L2 learning or teaching. This study employs the $C A$ theory to examine the differences between the segmental phonemes of English and Hausa languages in order to gauge the adverse effects of the situation on the Hausa ESL learners.

\section{REVIEW OF RELATED STUDIES}

The English language assumes different statuses in different parts of the world and different linguistic communities. Besides the native speakers who use it as an L1, many people use it as a Second or Foreign language [13]. However, the ESL and EFL users of English usually face similar problems. These problems or difficulties are 
mostly results of L1 intrusion in the L2 performance. The L1 is the immediate noticeable source of error among the ESL learners [10].

On this background, different studies have been conducted and different findings have emerged in attempts to remedy the tough situation of L1 interference in L2 or EFL learning. For example, [11] discovered that the dental fricatives $/ \theta /$ and $/ \delta /$ are missing in the Tiv language and the Tivs substitute $/ \theta /$ with $/ \mathrm{t} /$ and $/ \mathrm{d} /$ with $/ \mathrm{d} /$. The vowels $/ \mathrm{\partial} /$ and $/ æ /$ are not in Tiv, therefore speakers of this language face difficulties in producing these sounds. They found that $/ 1 /$ and $/ \mathrm{r} /$ are more of allophones in Tiv. Unlike in English where 'lice' and 'rice' are different words, 'lwam' and 'rwan' means the same in Tiv. Still, no Tiv word ends in either /s/ or /z/, therefore speakers of this language do not easily pronounce the English words ending in these sounds. This means that the Tivs needs thorough training to be able to pronounce the English sounds not found in their language, otherwise their spoken English would be something different from what they mean.

On the other hand, [9] conducted a study on Indonesian and English. He/she discovered that the ' $b$ ' is mostly /p/ word-finally in Indonesian. The / $/$ / sound is not in the Indonesian inventory. So this means the Indonesians ESL learners should pay more heed to these sounds avoid wrong pronunciation. Reference [14] researched English and Bangla sound systems. He discovered that while in English the vowel length results in difference of meanings (as in 'sheep' and 'ship'), this feature is not of any importance in Bangla. Both English and Bangla have diphthongs. But, as Barman discovered, while in English the first of the pair of vowels is longer, in the Bangla pair vowels have equal length. While English has 2 bilabial plosives (/p/ and /b/), Bangla has $4: / \mathrm{p} /, / \mathrm{p}^{\mathrm{h} /}, / \mathrm{b} /$ and $/ \mathrm{b}^{\mathrm{h}} /$. The aspiration also distinguishes meanings in Bangla, unlike in English. The glottal fricative $/ \mathrm{h} /$, which is sometimes silent in English (as in 'hour' and 'sigh'), is always pronounced in Bangla. Therefore a lot of errors would be made by Bangla ESL learners especially in the areas highlighted like pronouncing the English diphthongs pairs with equal length, giving short vowel instead of long one, and vice versa, aspirating sounds that are not supposed to be aspirated, and also pronouncing the $/ \mathrm{h} /$ in all positions.

Having come closer to the topic at hand, we focus on the study by [15]. Commenting on the phonological features of Nigerian English, Ekpe contends that these features affect the segmental sounds and supra-segmentals of the Nigerian ESL learners. The study discovered that most Nigerian speakers substitute $/ \mathrm{t} /$ for $/ \theta /$ and $/ \mathrm{d} /$ for $/ \delta /$, therefore 'thin' becomes [tin] and 'this' [diz]. He said this happens because most Nigerian languages do not have the dental fricatives. Ekpe went further and identified 3 broad varieties of Nigerian spoken English: NNEV (Northern Nigeria English Variety), SNEV (Southern Nigeria English Variety) and WNEV (Western Nigeria English Variety). The Hausa ESL variety falls under the NNEV.

Therefore, as the studies reviewed above focused on the description of English and other languages, this study focuses on the description of English and Hausa segmental phonemes. Furthermore, the study predicts areas of challenges likely to be faced by the Hausa ESL learners.

\section{MEthodology}

This study, like other contrastive analyses, is a secondary research. The study automatically lends itself to this approach because the segmental phonemes of English and Hausa languages have already been identified and described by earlier researches. The focus here was to compare and critically analyze the two classes of phonemes and see how being familiar with the Hausa phonemes can affect learning the English phonemes. We compared the phonemic inventories of these languages and also their distributions and realizations.

Because there are many accents of the two languages [7], [16]-[19] for this study, the researcher simply took the Standard accents of the two languages - English and Hausa. Therefore, although the English language has many dialects and accents, this study concentrated on the $R P$. This is because the RP is the accent being studied and used worldwide, not just in the areas where English is used as a first language. The other accents of English speech like Scottish, Irish, Welsh, Estuary, GA, Cockney, e.t.c were not be the focused on in this study. Most publications on the English phonemes are also based on $R P$ and not any other accent.

On the other hand, this study also focused on the Standard Hausa (Daidaitacciyar Hausa (D.H.)) and not any of the substandard accents like Katsinanci, Guddiranci, Zazzaganci, Sakkwatanci, Sakkwatanci etc. [17]. This was because the Standard Hausa is the accent being studied and used on the media locally across West Africa or globally like in the VOA, BBC, RFI, DW, CRI etc. The accent also has sufficient literature and is the one used for theatrical performances in Hausa.

\section{ENGLiSh AND HaUsa SEGMENTAL PHONEMES COMPARED}

The English language has a total of 44 phonemes (with the exception of the glottal stop [?] which is basically allophonic [7], [16] and [18]). All of these phonemes are produced using the pulmonic airstream - air movement initiated by the lungs. There are 24 consonants and 20 vowels. Out of the 20 vowels, 12 are pure vowels and 8 are diphthongs [7], [16], [18], [20]-[24] (shown in Tables I-II).

\section{A. English Consonants}

On the other hand, the Hausa language has 47 segmental phonemes, and the language uses both pulmonic and glottalic airstreams to produce its sounds [22], [6] and [20]. Therefore, while English has only pulmonic egressive sounds, Hausa has both pulmonic egressive and glottalic egressive and ingressive sounds. The Hausa consonants are 34 in number while the vowels are 13 . Out of the 13 vowels, 10 are pure vowels (long and short), and the remaining 3 are diphthongs. Hausa consonants are articulated in two ways: short and long (sound segmental length). This happens when a consonant appears twice where one closes the preceding syllable and the other opens the next as in rarrashi (pacify), and tattauna (discuss) [19] and [21]. While English uses consonant clusters, Hausa uses abutting consonants where consonants belong to two syllables instead of one as in jimla (sentence) maharbi (hunter) and 
sanda (cane). Some Hausa consonants have two levels of articulation as in kyankyaso (cockroach) gwani (expert) and fyade (rape) where all $/ \mathrm{kj} /, / \mathrm{gw} /$ and $/ \phi \mathrm{j} /$ have secondary articulations [17], [19]-[23].

TABLE I: ENGLISH RP CONSONANTS, BASED ON [7] and [16]

\begin{tabular}{|c|c|c|c|c|c|c|c|c|c|}
\hline & Bilabial & Labio-Dental & Dental & Alveolar & Post-Alveolar & Palatal & Velar & Labio- velar & Glottal \\
\hline Plosive & $\begin{array}{l}\mathbf{p} \\
\mathbf{b}\end{array}$ & & & $\begin{array}{l}\mathbf{t} \\
\mathrm{d}\end{array}$ & & & $\begin{array}{l}\mathbf{k} \\
\mathbf{g}\end{array}$ & & [?] \\
\hline Fricative & & $\begin{array}{l}\mathbf{f} \\
\mathbf{v}\end{array}$ & $\begin{array}{l}\boldsymbol{\theta} \\
\boldsymbol{\partial}\end{array}$ & $\begin{array}{l}\mathbf{S} \\
\mathbf{z}\end{array}$ & $\begin{array}{l}\int \\
3\end{array}$ & & & & h \\
\hline Affricate & & & & & $\begin{array}{l}\text { t\} } \\
\text { d3 }\end{array}$ & & & & \\
\hline Nasal & $\mathbf{m}$ & & & $\mathrm{n}$ & & & y & & \\
\hline Lateral & & & & 1 & & & & & \\
\hline Approximant & & & & & $\mathbf{r}$ & $\mathbf{j}$ & & $\mathbf{w}$ & \\
\hline
\end{tabular}

\section{B. Hausa Consonants}

TABLE II: HAUSA D.H CONSONANTS, BASED ON [6], [17], [19], [21]-[23]

\begin{tabular}{|c|c|c|c|c|c|}
\hline & Description & Sound & & Description & Sound \\
\hline 1 & $\begin{array}{l}\text { Bilabial } \\
\text { plosive }\end{array}$ & $\bar{b}$ & 15 & Alveolar nasal & $\mathbf{n}$ \\
\hline 2 & $\begin{array}{l}\text { Alveolar } \\
\text { plosive }\end{array}$ & $\begin{array}{l}t \\
d\end{array}$ & 16 & Palatal nasal & $\mathbf{n}$ \\
\hline 3 & Velar plosive & $\begin{array}{l}\mathbf{k} \\
\mathbf{g} \\
\end{array}$ & 17 & Velar nasal & y \\
\hline 4 & $\begin{array}{l}\text { Labialized } \\
\text { velar } \\
\text { plosive }\end{array}$ & $\begin{array}{l}\text { kw } \\
\text { gw }\end{array}$ & 18 & Bilabial fricative & \\
\hline 5 & $\begin{array}{l}\text { Palatalized } \\
\text { velar plosive }\end{array}$ & $\begin{array}{l}\mathbf{k j} \\
\mathbf{g j}\end{array}$ & 19 & $\begin{array}{l}\text { Palatalized } \\
\text { bilabial } \\
\text { Fricative }\end{array}$ & $\phi \mathbf{j}$ \\
\hline 6 & $\begin{array}{l}\text { Glottal } \\
\text { plosive }\end{array}$ & $?$ & 20 & Alveolar fricative & $\begin{array}{l}\mathbf{s} \\
\mathbf{z}\end{array}$ \\
\hline 7 & $\begin{array}{l}\text { Palatalized } \\
\text { glottal }\end{array}$ & $? \mathbf{j}$ & 21 & $\begin{array}{l}\text { Post-alveolar } \\
\text { fricative }\end{array}$ & $\int$ \\
\hline 8 & $\begin{array}{l}\text { Bilabial } \\
\text { implosive }\end{array}$ & b & 22 & Glottal fricative & h \\
\hline 9 & $\begin{array}{l}\text { Retroflex } \\
\text { implosive }\end{array}$ & $\bar{d}$ & 23 & $\begin{array}{l}\text { Post-alveolar } \\
\text { affricate }\end{array}$ & $\begin{array}{l}\text { tf } \\
\text { d3 }\end{array}$ \\
\hline 10 & $\begin{array}{l}\text { Alveolar } \\
\text { ejective }\end{array}$ & $\mathbf{s}^{\prime}$ & 24 & Alveolar lateral & I \\
\hline 11 & $\begin{array}{l}\text { Velar } \\
\text { ejective }\end{array}$ & $\mathbf{K}^{\prime}$ & 25 & Alveolar Trill/roll & $\mathbf{r}$ \\
\hline 12 & $\begin{array}{l}\text { Labialized } \\
\text { velar } \\
\text { Ejective }\end{array}$ & $\begin{array}{l}\mathbf{K}^{\prime} \mathbf{w} \\
-\end{array}$ & 26 & Retroflex flap & r \\
\hline 13 & $\begin{array}{l}\text { Palatalized } \\
\text { velar ejective }\end{array}$ & $\mathbf{K}^{\prime} \mathbf{j}$ & 27 & $\begin{array}{l}\text { Palatal } \\
\text { approximant }\end{array}$ & $\mathbf{j}$ \\
\hline 14 & $\begin{array}{l}\text { Bilabial } \\
\text { nasal }\end{array}$ & $\mathbf{m}$ & 28 & $\begin{array}{l}\text { Labio velar } \\
\text { approximant }\end{array}$ & $\mathbf{W}$ \\
\hline
\end{tabular}

\section{English and Hausa Consonants Compared}

Plosives: while the English language has a total of 6 plosives (the glottal stop / / being an allophone): / p b t d k g /, Hausa language has 11: / b t d k g kw gw kj gj ? ?j /. However, the Hausa implosives / $\mathbf{b} /$ and /d/ and the ejectives $/ \mathbf{s}^{\prime} /, / \mathbf{k}^{\prime} /, / \mathbf{k}^{\prime} \mathbf{w} /$ and $/ \mathbf{k}^{\prime} \mathbf{y} /$, which are glottalic sounds, can also be described as plosive consonants because of the plosion as the articulators abruptly separate [16]. The English language does not have any implosive or ejective. The plosive /p/ is missing in the Hausa inventory and English also lacks / kw gw kj gj and $\mathbf{2 j} /$. These are some of the Hausa consonants with two levels of articulation [21]. The two languages share the plosives / b t d k g/.

On the distribution and realization of these plosives in the two languages, you discover that while / p b t d k g / can occur in all positions in English words [7], [16] and [18], the sounds /b d g/ do not come word-finally in Hausa [17] and [21]. In English, the sounds / b d g / lose their voicing word-initially and finally (as in begin, dark and govern) [7] and [16], these sound in Hausa are never devoiced in all positions. The English plosives are also used in clusters but Hausa does not use consonant clusters [21] and [22]. Hausa uses its plosives as long consonants (tsayin sauti) as in words like babba (big), gaggawa (haste) and hadda (memorize) where we have the long /bb/, /gg/ and /dd/ respectively. In the articulation of each of these consonants, a longer duration of time is taken keeping the articulators tightly closed before an abrupt release [19]. English plosives do not behave like this.

On the other hand, while the English plosive are sometimes silent (as in com $\underline{b}$, psyche and castle), the Hausa plosives are always pronounced. The glottal stop [?], which is not a significant sound in English, is a full phoneme in Hausa, with the orthographic shape [']. The glottal stop (Hamza) in Hausa is also realized in words beginning with vowels because vowels do not operate word-initially in Hausa -as in [?anjima] (later) and [?umurni] (permission) [6] and [21]. Glottalization (Hamzantawa) accompanies words ending with short vowels that are either pronounced in isolation or as last words of structures -as in [gobe?] (tomorrow) and [dazu?] (moments ago). Words ending with diphthongs or long vowels are not glottalized - as in ja [dza:] (red) and kai [kai] (head) [22].

Fricatives: the English fricative consonants / f v $\boldsymbol{\theta}$ ठ $\mathbf{s} \mathbf{z} \int$ $\mathbf{3} \mathbf{h} /$ are 9 in number but Hausa has only 6 / $\boldsymbol{\phi} \boldsymbol{\phi j} \mathbf{s} \mathbf{z} \int \mathbf{h} /$. Therefore, the sounds: / f $\mathbf{v} \boldsymbol{\theta} \boldsymbol{\partial}_{3} /$ are missing in the Hausa inventory and the two languages share: / $\mathbf{s} \mathbf{z} \int \mathbf{h} /$. From a point of view, ESL learners whose L1 lacks /ө/ and /ठ/ use /t/ and /d/ instead [7]. The English /s/, when used after a voiced sound as in needs and begs, assumes voicing and is therefore realized as /z/ [18]. But, the Hausa /s/ always maintains its voicelessness even after a voiced sound as in tilas (must) and tabbas (sure) [21]. While the English /z/ is sometimes ' $\mathrm{s}$ ' in spelling (as in lose and nose), the Hausa $/ \mathbf{z} /$ is always written as ' $z$ '. The $/ \boldsymbol{j} /$ sound in English is represented by different combination of letters like 'sh' shop, 'ch' -chef, 't' - militia, 'ss' -mission e.t.c, the Hausa $/ \mathbf{f} /$ is always 'sh'. The sound $/ \mathbf{h} /$ does not occur word-finally after vowels in both the languages.

Affricates: both Hausa and English have two affricates only: /t $\mathbf{\int} \mathbf{d} \mathbf{z} /$. the sound / $\mathbf{t} \mathbf{j} /$ occurs in English as ' $\mathrm{t}$ ', 'ch' or 'tch' [25] as in lecture, chew, and watch but in Hausa it is always occurs as 'c' [21] as in cuta (disease) and caca (gambling). It occurs in all positions in English but it does not occur word-finally in Hausa. On the other hand, the sound /dz/ is spelt only as ' $\mathrm{j}$ ' in Hausa but in English it occurs as 'j', 'gg', 'dj', 'ch', 'de', 'd', and 'g' as in just, 
gaol, soldier, digest etc. in English, it occurs initially, medially and finally but in Hausa it occurs only initially and medially as in lauje (sickle) janye (withdraw).

Nasals: while English has 3 nasal sounds /m n $\mathbf{y} /$, the Hausa language has 4: /m n $\mathbf{n} \mathbf{\eta} /$. The English nasals are spelt differently as 'mm', 'mn', 'nn', 'gn', 'kn', 'ng', 'nk' etc respectively, while Hausa /m n/ occur as ' $m$ ' and ' $n$ ' but $/ \mathbf{n} /$ and $/ \mathbf{y} /$ basically occur as allophones of $/ \mathbf{n} /$. /n/ occurs word-finally as in cay (there) and nay (here) or syllablefinally before a velar sound as in baygo (wall) and ninka (double) [21]. The $/ \mathbf{j} /$ is a palatalized nasal and is always realized in the combination 'ny' as in hanya (road) and kunya (shyness). $/ \mathbf{m} /$ and $/ \mathbf{n} /$ can both occur in all positions in English but in Hausa /n/ becomes /y/ word-finally. /y/ does not occur in initial position in both, and $/ \mathbf{n} /$ in Hausa is restricted to medial position. Nasal sounds are all voiced but when they follow /s/ in initial cluster in English they become devoiced as in snail and smuggle [24]. However, because Hausa has no consonant clusters, its nasals are always voiced and they do not occur as syllabic [22] like in English cotton and column.

Laterals: the lateral sound in both English and Hausa is the /1/. This sound occurs in English as either ' 1 ' or ' 11 ' but Hausa always has it as ' 1 '. in English, when /1/ occurs before a vowel or $/ \mathrm{j} /$ as in look, live or value, it is clear [1]; and when it occurs after a vowel as in kneel, full or skill, or before another consonant as in feels and deals, it is dark [1]. The $/ 1 /$ is devoiced after $/ \mathrm{p} /$ or $/ \mathrm{k} /$ as in please, people, clean and close [7], [16] and [24]. The Hausa language does not use consonant clusters and the $/ 1 /$ in Hausa is fully voiced in all positions [21] and [22]. Finally, while the English /1/ is sometimes silent as in palm, calf and should, the Hausa /1/ is always pronounced.

Approximants: the English language has three approximants but Hausa has only two. The English approximants include: $/ \mathbf{r} \mathbf{j} \mathbf{w} /$, while the Hausa approximants are /j w /. The Approximants, Trill/roll and Flap: the English RP does not have any Trill or Flap but the Hausa language uses the trill /r/ and the Flap /r/. The English /r/, which is a post-alveolar approximant, contrasts with the Hausa /r/, which is an alveolar trill/roll. The Hausa $/ \mathbf{r} /$ is unique and is not found in English. The Hausa $/ \mathbf{r} /$ is articulated in two ways $/ \mathbf{r} /$ and $/ \mathbf{r} /$, and like the other ESL users, the Hausas too will face problem in not pronouncing the sound [16]. This is because while in English it occurs only before vowels, in Hausa it also appears after vowels and it is always pronounced. But the English $/ \mathbf{j} /$ and $/ \mathbf{w} /$ are similar to those in Hausa. In Hausa, the two sounds are restricted to onset position as in yabo (praise) and baya (back), wando (trousers) wasu (some). The two can also come as coda elements of medial geminate glide as in tarbiyya (discipline) dawwama (eternity) [6] and [22].

\section{English and Hausa Vowels Compared}

The English language has a total of 20 vowels. Out of these, 12 are pure vowels and eight are diphthongs. The English 12 pure vowels comprise of 7 short vowels: /i/, /e/,

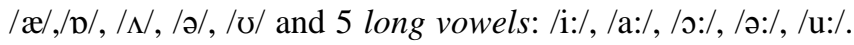
The vowel system of English is so complex that it is among the less common among languages and it is absolutely predictable that ESL learners will have trouble in learning them [7] and [16]. On the other hand, the Hausa has 13 vowels - 10 pure and 3 diphthongs. The pure vowels are composed of 5 short: /i/, /e/, /D/, /a/, / / / and 5 long equivalents: /i:/, /e:/, /o:/,/a:/, /u:/. Therefore, we have 5 pairs of two vowels where one is short and the other long. The diphthongs include: /ai/, /au/, and /ui/ [5], [6], [17] and [21]. These vowels are displayed as follows:

\section{E. English and Hausa Vowels}

TABLE III: ENGLISH AND HAUSA VOWELS

\begin{tabular}{|c|c|}
\hline English & Hausa \\
\hline Pure vowels : & Pure vowels: \\
\hline 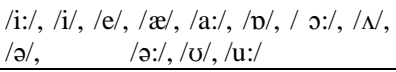 & $\begin{array}{l}\text { /i:/, /i/, /e:/, /e/, /o:/, /v/, /a:/, /a/, } \\
/ \text { u:/,/o/ }\end{array}$ \\
\hline Diphthongs: & Diphthongs: \\
\hline $\begin{array}{l}\text { /ei/, /ai/, /əi/, /iə/,/eə/, /uə/, /au/, } \\
\text { /əu/ }\end{array}$ & /ai/, /au/, /ui/ \\
\hline
\end{tabular}

Pure Vowels: while the pure vowels of English are spelt differently ( e.g. /i/ is spelt 'i', 'a', 'e' as in sit, private and wicked, /a:/ is spelt 'a', 'al', 'ear' as in father, palm and heart), the Hausa pure vowels always have unique spelling ( e.g. /a/ is spelt 'a' as in tafiya (walking) and mace (woman)). But the Hausa long and short vowels are spelt alike, and it is only the phonetic realizations of the vowels that distinguish the meanings of words [21] and [22]. For example, [ga:fi] (hair) and [gafi:] (roast) are both spelt 'gashi'; [dza:ka] (female donkey) and [dzaka:] (bag) are both spelt 'jaka'. Words are spelt exactly the the same but pronounced differently [17]. The vowels: /æ/, / / /, /ə/, /ə:/ are missing in the Hausa vowel system but they are used in English and these are among the most difficult to learners whose L1 is not English [7] (shown in Table III).

While vowels occur in all positions in English [16], no vowel operates initially in Hausa. Vowels in Hausa can only occur medially and finally. A word may seemingly begin with a vowel but because of the Hausa canonical restriction that all syllables must have onsets, a glottal stop is realized before the vowel -as in [?amarja] (bride) and [?ilmi] (education) which are spelt 'amarya' and 'ilmi' respectively. However, unless for long vowels and diphthongs, vowels syllable-finally are also glottalized [6] and [21]. While in English a long vowel or diphthong can occur as the nucleus of closed syllables -as in feed, taught, laugh, gate and dine; in Hausa neither a long vowel nor a diphthong occurs as nucleus of closed syllable. Even when a syllable originally has a long vowel or diphthong as its nucleus, the moment it is added a suffix it automatically becomes a short one -as in [dan] (the son), [?jar] (the daughter) and [man] (the oil) which were originally [da:] (son), [?ja:] (daughter) and [mai] (oil) respectively [21] and [22]. Contrastively, short vowels, long vowels and even diphthongs can all play the nucleic role in open syllables. Although Hausa syllables ending with short vowels - word finally or in isolation -are glottalized, those with long vowels or diphthongs are not. This does not happen in English because vowels shorten only before voiceless consonants but they lengthen before voiced ones [7]. The phonetic realizations of Hausa short vowels medially vary in accordance with the surrounding consonantal and vocalic environments. For example, /u/ is anticipatorily assimilated to /i/ when it precedes a syllable 
with $/ \mathrm{i} /$ as the nucleus (e.g. buki $\rightarrow$ biki) (celebration), or when it precedes the $/ \mathrm{j} /$ sound (e.g. wuya $\rightarrow$ wiya) (neck) vowels that can precede $/ \mathrm{j} /$ and $/ \mathrm{w} /$ are only $/ \mathrm{i} /$ and $/ \mathrm{u} /[6]$.

Diphthongs: this is an area of great differences between the English and Hausa sound system. While the English language has 8 diphthongs: /ei/, /ai/, / ì/, /iə/,/eə/, /uə/, /au/, /ou/ [7], [16] and [18], Hausa language has only 3: /ai/, /au/ and /ui/ [6], [17] and [21]. It can be seen that only two: /au/ and /ai/ are similar in the two languages. The English diphthongs usually pose problems to the ESL learners. These learners usually produce pure vowels when diphthongs are expected [16]. For example, they will use /p/ instead of /ou/ or /e/ instead of /ei/ so that go is [gp] and gate is [get] [7]. In English, diphthongs are spelt differently (e.g. /oi/ toy, coin and buoy; /ai/ dine, try, tie and night e.t.c.) [25], but Hausa diphthongs are always spelt as they are pronounced (e.g. /ui/ kwuibi (side), /au/ farauta (hunting) and /ai/ saida (sell) etc) [19] and [22].

In pronouncing the English diphthongs, the first vowel should be longer than the second, and this is also a problem to L2 learners because they mostly give equal length to both the elements and makes their speech odd [7]. Respect of Hausa ESL learners, this is attributable to the fact that the diphthongs in Hausa are pronounced with equal length. While in English a diphthong can occur as a nucleus in both open and closed syllables (as in twilight, late, out and pay)), no diphthong performs nucleic function in Hausa closed syllables. Because no vowel occurs syllable-initially in Hausa, diphthongs cannot begin Hausa words but English has words like isle, oil, owl e.t.c which begin with the diphthongs: /ai/, /oi/ and /au/ respectively.

\section{DISCUSSION}

We have explored the English and Hausa segmental phonemes and we have understood that although the languages share some similar phonemes, there have been significant differences between their phonemic systems. While English has 44 phonemes, Hausa has 47. And, when all English phonemes are produced with the pulmonic airstream, Hausa phonemes are produced using both pulmonic and glottalic airstreams. To begin with, the English language has a total of 24 consonants and Hausa language has a total of 34 . Although 18 of the English consonants are similar to Hausa consonants, they have different allophonic variations in the two languages. While English uses consonant clusters, Hausa uses long consonants and abutting consonants. Unlike English where some sounds are silent, the Hausa consonants are always pronounced and a syllable must always begin with a consonant.

On the other hand, a careful study of the vowel systems of the two languages also revealed that great deal of differences occurs between them. In the first place, English has a total of 20 vowels but Hausa has only 13. The vowels of each language can be classed into two: pure vowels and diphthongs, where English has 12 pure vowels and 3 diphthongs. While each English vowel is spelt in different ways, the Hausa vowels always have unique orthographic shape. The Hausa long and short vowels are spelt alike and vowel length has semantic impact. While all short, long and diphthong vowels can operate as inucleus in English closed syllables, only short vowels occur as nucleus in Hausa closed syllables.

Studies of this nature have always been carried out in order to diagnose the similarities and differences between phonemes of languages so that areas of possible difficulties are predicted especially in the ESL/EFL learning. This helps also in the areas of material development and language assessment. For example, [8] compared English and Cantonese, and they predicted different phonological differences faced by the Cantonese ESL learners. [26] was a comparison between Kurdish and English and [12] compared Japanese and English. All of these studies explored the phonemic systems of the languages and predicted different pitfalls for the ESL/EFL learners.

\section{Predictions}

Based on the findings of this study, the following areas of difficulties among the Hausa ESL learners are hereby predicted:

1) The Hausa ESL learners would have difficulty pronouncing all the consonants / p f $\mathbf{v}$ o $\partial 3 /$ The Hausa speakers are likely to pronounce /p/ and /f/ as $/ \phi /$ so that pen is $[\phi e n]$ and friend is $[\phi r e n]$. They are likely to have /v/as /b/, /ө/ as /t/, /ð/ as /d/, and /3/ as /dz/.

2) Because the English vowels / /a/, / / /, /ə/, /ə:/ /iə/,/eə/, /uə/, /əu/ are not similar to those in Hausa, therefore the Hausa ESL learners would find them hard to learn. The vowels /æ/ and $/ \mathbf{\Lambda} /$ are likely to be heard as $/ \mathbf{a} /$, while /ə/ and /ə:/ as /e/, /iə/ as /ai/, /eə/ as /ea/, /uə/ as /ua/, and /əu/ as /p/ respectively. They will always attempt to use native phonemes instead of English ones.

3) The Hausa ESL learners will glottalize any vowel syllable-initially or any short vowel syllable-finally in isolated or last words.

4) Because the Hausa phonemes are always pronounced, the Hausa ESL learners would have difficulty in leaving a letter(s) unpronounced.

5) The Hausa ESL learners would mistake the combination of letters like 'll', 'mm', ' $\mathrm{tt}$ ', e.t.c as long consonants that should be longer than when single letters are used.

6) Even after a voiced sound, the Hausa ESL learners would pronounce ' $d$ ' as /d/ instead of /t/ especially when regular verbs are in past form. This is because the Hausa /d/ is never devoiced.

7) The Hausa ESL learners are most likely to pronounce the English diphthongs wrongly, especially the ones not similar to those in Hausa. Learners are likely to use pure vowels instead of diphthongs or give the two sounds equal length.

\section{ACKNOWLEDGMENT}

Zubairu Malah appreciates the untiring guidance and support from Dr. Sabariah Bt. Md. Rashid, the H.O.D. English, UPM, in writing this paper. Profound appreciations also go to Prof. Ahmed Gimba and Dr. Moh'd Meleh, of UNIMAID, and Dr. Cliffort Irikefe Gbenyorong, of Yobe State University Damaturu, Nigeria. 


\section{REFERENCES}

[1] F. R. Eckman, From Phonetic Differences to Constraint Rankings, Milwaukee: University of Wisconsin, 2004, pp. 515-530.

[2] H. D. Brown, Principles of Language Learning and Teaching, $6^{\text {th }}$ ed. New York: Pearson Education, 2014, ch. 9, pp. 242-276.

[3] J. Jenkins, The Phonology of English as an International Language, Oxford: Oxford University Press, 2008, pp. 33-39.

[4] R. Lado, Linguistics Across Cultures, Ann Arbor: University of Michigan, 1957, pp. 1-20.

[5] P. Newman, The Hausa Language: An Encyclopedic Reference Grammar, New Haren: Yale University Press, 2000, pp. 1-10.

[6] P. J. Jaggar, Hausa, Armsterdam/Philadelphia: John Benjamin Publishing Com., 2001, ch. 2.

[7] A. Cruttenden, Gimson's Pronunciation of English, $6^{\text {th }}$ ed. London: Arnold International Publishers, 2001, pp. 91-216.

[8] Y. W. A. Chan and L. I. David. (April 2010). English and Cantonese phonology in contrast: Explaining Cantonese ESL learners' English phonological problems. Language, Culture and Curriculum. [Online] 13(1). pp. 67-85. Available: http://dx.doi.org/10.1080/07908310008666590

[9] A. Baso. (September 2013). A comparative analysis between English and Indonesian phonological system. IJELE. [Online]. Available: http://www.macrothink.org/ijele

[10] G. Yule, The Study of Language, Cambridge: Cambridge University Press, 2007, ch. 1-3.

[11] D. T. Waya and S. T. Kwambehar. (January 2014). A phonetic contrastive analysis of Tiv and English segmentals. IJSS. [Online]. pp. 12-14. Available: https://scholar.google.com.my/scholar?hl=en\&q=waya+and+kwamb ehar\&btnG=\&as_sdt=1\%2C5\&as_sdtp=

[12] K. Ohata. (September 2004). Phonological differences between Japanese and English: Several potentially problematic areas of pronunciation for Japanese ESL/EFL learners. AEJ. [Online]. pp. 1$19 . \quad$ Available: https://scholar.google.com.my/scholar?hl=en\&q=kota+ohata\&btnG= \&as_sdt=1\%2C5\&as_sdtp=

[13] J. Lyons, Language and Linguistics, Cambridge: Cambridge University Press, 2009, ch. 2-5.

[14] B. Barman. (August 2010). A contrastive analysis of English and Bangla phonemics. DUJL. [Online]. pp. 19-42. Available: https://scholar.google.com.my/scholar?hl=en\&q=barman+on+english + and+bangla $+\&$ btnG $=\&$ as_sdt $=1 \% 2 \mathrm{C} 5 \&$ as_sdtp=

[15] M. B. Ekpe, The English Language in Nigeria, Lagos: National Open University of Nigeria, 2010, pp. 61-90.

[16] P. Roach, English Phonetics and Phonology, $3^{\text {rd }}$ ed. Cambridge: Cambridge University Press, 2000, pp. 19-80.

[17] M. A. Z. Sani, Siffofin Daidaitacciyar Hausa, Kano: Benchmark Publishers Ltd, 2009, pp. 6-22.

[18] A. McMahon, An Introduction to English Phonology, Edinburgh: Edinburgh University Press Ltd., 2002, pp. 12-91.

[19] M. A. Z. Sani, Maraka Yanki A Tsarin Sautin Hausa, Zaria: Ahmadu Bello University Press, 2013, pp. 1-87.

[20] P. Ladefoged, A Course in Phonetics, Oxford: Blackwell, 2013, ch. $1-3$.
[21] M. A. Z. Sani, An Introductory Phonology of Hausa, Kano: Benchmark Publishers Ltd., 2005, ch. 1-4.

[22] M. A. Z. Sani, Gamayyar Tasrifi Da Tsarin Sautin Hausa, Zaria: Ahmadu Bello University Press, 2011, pp. 1-49.

[23] R. M. Zarruk, Shimfidar Ilmin Harsuna a Hausa: Furuci, Zaria: ABU Press, 1996, pp. 1-27.

[24] C. Beverley and M. M. Inger, Practical Phonetics and Phonology, New York: Routledge Publishers, 2008, pp. 79-105.

[25] J. Demola, Phonology of English, Lagos: National Open University of Nigeria, 2010, pp. 19-111.

[26] R. Massoud. (September 2011). A phonological contrastive analysis of Kurdish and English. IJEL. [Online]. pp. 73-82. Available: http://www.doi:10.5539/ijel.vln2p73

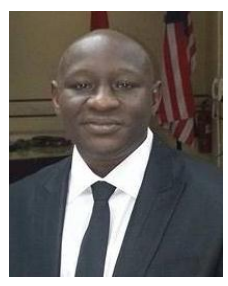

Zubairu Malah was born in Gashua, Yobe State of Nigeria, on the December 25, 1980. After his primary and secondary education, Zubairu obtained an NCE in English/Hausa (at distinction level) from the College of Education Gashua (COEGA) in 2001. He furthered his career by earning a B.A. English language degree (second class, upper division) from the University of Maiduguri Nigeria, in 2007 Zubairu is currently pursuing M.A. degree in English language at Universiti Putra Malaysia.

He has been a lecturer at Yobe State University, Damaturu since 2011; but before his appointment with the University, Zubairu had lectured English at the Nigerian Teachers' Institute (NTI) center in Damaturu. He was also a teacher of English and Hausa languages in both primary and secondary schools within and outside Yobe State since 2001. His areas of research interest include contact linguistics, discourse analysis, phonetics and phonology, literature and pragmatics.

Mr. Malah has been a member of the Nigerian Academic Staff Union of Universities (ASUU). He has also been a member of the English Language Teachers' Association of Nigeria (ELTAN). Still a proudly registered teacher! He holds two outstanding awards: Father Daly's Award for the Best Graduating Student of English, UNIMAID 2007; and also COEGA Award for the Best Graduating Student of English/Hausa, 2001. His latest publication was on English-Malay Loanblends, and is currently working on cohesion/ coherence and textualilty in texts.

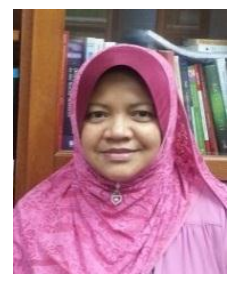

Sabariah Md. Rashid is a senior lecturer and the current head of the Department of English, Faculty of Modern Languages and Communication, University Putra Malaysia. She holds a Ph.D. degree in English studies from University of Kabangsan Malaysia, 2011 with focus on the analysis of metaphorical expressions using the cognitive semantics framework. Before she received her M.Phil degree in 1999 from University of Reading, UK, she had obtained an M.A. degree in applied linguistics from the same university in 1993. Her B.A. degree in language studies was obtained in 1986 from University of Essex, UK. She carries out researches and publishes mainly in the areas of applied linguistics, language testing, and language and meaning, in particular, in cognitive semantics. 